\title{
The Role of Inappropriate Agricultural Practices on Soil Degradation in the Eastern Cape: the Case of Farming at Sheshegu Community
}

\author{
Lewu B. Francis and Ighodaro Ikponmwosa David*
}

\begin{abstract}
This study examines the role inappropriate agricultural activities play in erosion development in the Eastern Cape, using the case study of Sheshegu community, South Africa. A cross-sectional data, collected through a random sampling collection process, from 50 smallholder farmers, form the basis of the study. According to findings, though several anthropogenic variables were mentioned as influencing factors on the Sheshegu soil erosion, agriculture-related activities were perceived higher (47\%) in importance, and its level of impact was ranked as high as $90 \%$. This finding was also corroborated by other results, as income from agricultural production $(29.4 \%)$ contributed the most to farmers' overall income, and free-range animal production system (64\%), a system known to be soil erosion-prone, ranked the most out of all farmers' production system. Since livestock farming is the main source of income for farmers in the area, farmers should be supported to establish closed-range lands for their livestock.
\end{abstract}

Key words - Anthropogenic activities, inappropriate agricultural practices, Eastern Cape, Sheshegu community, Soil erosion.

\section{INTRODUCTION}

The fact that agricultural activity plays significant roles in soil erosion/degradation has been well acknowledged. One obvious reason is because agriculture provides over $99.7 \%$ of all human foods [1], [2], making it the closest activity to the soil. The case is compounded with the current global population growth rate and the overwhelming need to meet the food supply requirements of this growth. Indications are that, 79.3 million people (83 million, according to the World Economic Forum 2017) are added to the world population annually; a figure said to have remained constant for almost a decade [3]. The worry, is that with this growth rate, agricultural production must increase by $70 \%$ to be able to meet up with this trend by 2050 [4], [5], [6]. In fact, the current demand for food has been predicted to double by 2050 , exerting unimaginable pressures upon natural resources [4]. This is why Nearing et al. [7] and Meijer et al. [8] both emphasize that the increasing global population has led to increased agricultural intensification and land use pressures, resulting in soil and land degradation.

Soil erosion (degradation) is regarded as one of the world's most significant environmental problems due to its impacts on

This paper was submitted on the $13^{\text {th }}$ of July, 2020; F.B. Lewu is the HOD and Professor of Soil Science and Botany (with specialization in plant genetic conservation and propagation), I.D. Ighodaro is a Postdoctoral Research Fellow, both from the Department of Agriculture, Faculty of Applied Sciences, Cape Peninsula University of Technology, Wellington Campus, South Africa both the natural environment and the human society [9]. Soil erosion is commonly regarded as the greatest threat to land productivity, leading to adverse effects on agricultural production, infrastructure and quality of water [10]. It has the capacity to reduce rooting depth, soil fertility, soil organic matter and plant-available water reserves, as well as a global challenge for sustainable agricultural production [11]. Supporting this, Issaka and Ashraf [12] maintain that soil erosion negatively hinders plant growth, farm yields, water quality and recreation. Almost $22 \%$ of all global cropland, pasture, forest and woodland have been degraded since the past century; which in financial terms, is approximately an annual loss of US\$28 billion as a result of degradation in global drylands [9].

Indications are that, degradation of the soil is usually a main problem of less developed areas of the world, particularly in places where agriculture is a major source of economic development [5]. This is largely due to factors such as poverty, inadequate technologies and know-hows, and high population growth, which engender improper use of natural resources such as the soil. Degradation is set in motion, often by inappropriate use of land or soil along with extractive farming; a process which feeds on itself in an ever increasing downward spiral [5]. According to Pender and Hazell [13], poverty, low agricultural productivity, and natural resource degradation are very serious interrelated challenges in less-favoured areas such as sub-Saharan Africa. The widespread occurrence of degraded soils in sub-Saharan Africa is a real example of the downward spiral, a problem caused by over exploitation, extractive farming, low external inputs, and poor or improper soil management [5].

Although soil erosion is a natural process, it is however exacerbated by human activities, especially that which relates to clearance of vegetation, such as for agriculture. Thus, the soil is exposed to various agents of denudation. Changes in land use have been widely recognized as having the potential of being able to accelerate the processes of soil erosion [14]. In cropping systems, soil erosion/degradation is propelled by inappropriate management practices which bring about reduction in soil biological, chemical and physical quality, resulting to the inability of the soil to support production and environmental functions [15]. Garland et al. [16] conclude based on evidences, that though South Africa is predisposed to soil erosion due to factors such as the sensitive and fragile nature of its soils, as well as the climate and topography of the area, the most 
influential factor however is poor farming and land husbandry by both smallholder and large scale farmers.

Seventy percent of the surface land area of South Africa is said to be affected by varying levels and types of soil erosion [17]. Areas of most degradation are the communal areas of the former homeland, where majority of smallholder farmers dwell [18], [19]. These areas are generally characterized with soil degradation and poverty, part of the consequences of apartheid policies. As it is well known, the former homeland areas were only $13 \%$ of total land areas in South Africa, where black people were forced to live during apartheid regimes. As such, apart from the problem of poverty, the competition for usable land due to population density is said to be one reason why such areas are still the most degraded in South Africa. For instance, the Eastern Cape Province, where this study consists, one of the former homeland areas of Ciskei and Transkei, is regarded as one of the three most degraded provinces in South Africa [20], [21]. Also, the province is classified as one of the poorest provinces in South Africa [22], [23]. Based on annual ratings, it was emphasized that the Eastern Cape, KwaZulu-Natal, and Limpopo provinces featured consistently as the three poorest provinces between 2006 and 2015, in South Africa [24]

Further information on the Eastern Cape, Limpopo and KwaZulu-Natal Provinces, indicate that very huge proportions of the land are under severe threat of soil erosion [25]. In fact, when a relative provincial soil loss comparisons were made, the Eastern Cape Province was found to make the most contribution (28\%) to soil loss in South Africa; and about one third (16 million ha) or $37 \%$ of the entire province is classified as having moderate to extremely high soil loss [25], emphasizing the level of degradation in the province.

The foregoing provides a general overview of pre-existing conditions and reasons for the soil erosion situation of the Eastern Cape. However, this current study seeks to ascertain specific factors, especially as it relates to the study area. Therefore, the goal of this paper is to determine the role inappropriate agricultural practices play in the soil erosion development of the Eastern Cape Province, using the farming situation of Sheshegu community as a case study. In order to achieve this objective, the following specific objectives are specified: (1) to establish the role agricultural activities play in soil erosion development in the study area; (2) to assess farmers' perception on impact of agricultural practices on soil erosion development in the study area; and (3) to determine the basic inappropriate agricultural activities responsible for soil erosion situation of the study area. The expectation is that findings of this study will add to existing literature on causes of soil erosion/degradation in the Eastern Cape, and thus encourage policies to ameliorate the problem.

\section{Methodology}

\section{A. Characteristics of Study Area}

The study was conducted in Sheshegu community, a rural community, located in Raymond Mhlaba local municipality, Eastern Cape of South Africa. Sheshegu community is located on the south-west of Alice town, along the R345 road to Peddie. It is positioned on longitude $26^{\circ} 44^{\prime} 47^{\prime \prime} .9$ and $26^{\circ} 50^{\prime} 55^{\prime \prime} .2 \mathrm{E}$ of
Greenwich, and latitude $32^{\circ} 53^{\prime} 06^{\prime \prime} .1 \mathrm{~S}$ and $32^{\circ} 56^{\prime} 36^{\prime \prime} .0 \mathrm{~S}$ of the equator [26], with an elevation of $563 \mathrm{~m}$ above sea level [27]. The community comprises of the following villages, namely Mpozisa, Skolwoni, Baluia, Lower Sheshegu, Sheshegu Fingo and Komkhalu, respectively. Its lithology is mostly mudstone and sandstone, and its vegetation is part of the Valley Bushveld in the Thicket Biome. The area receives an average rainfall of about $386 \mathrm{~mm}$ annually, with most of the rainfall experienced during summer [28]. Average daily temperatures in the area range between a minimum of $19^{\circ} \mathrm{C}$ in June, to a maximum of $28^{\circ} \mathrm{C}$ in February, respectively. The inhabitants of the area are mainly Xhosa speaking, and their main occupation is livestock farming, as well as small level of crop production [29]. According to Statistics South Africa [30], the main land use type of Sheshegu community is sheep farming, although other animal production systems also occur in the area.

\section{B. Data Collection and Analysis}

Data for this paper forms part of a larger study, conducted in 2010. Using the cross-sectional research design method, by a random sampling selection process, data for the study was collected from 50 smallholder farmers in the study area. Collection instrument was a semi-structured questionnaire, through a one-on-one collection process. With the help of the extension department (Department of Agriculture, Forestry and Fisheries [DAFF], Alice) in the study area, farmers' cooperation was solicited to ensure smooth data collection process. Specific variables collected and analysed for this study are: the perceived basic causes of soil erosion in the study area; the perceived role agricultural activities play in soil erosion development in the study area; the relative contribution of various sources of income to overall income of farmers; and farming systems practiced by farmers in the area. Data collected were analysed with the statistical package for the social sciences (SPSS) software package version 19, using basic descriptive statistics such as frequencies, percentages, means, and graph. Table 1 is a tabular presentation of all variables analyzed for the study..

\section{RESULTS AND DISCUSSION}

\section{A. Socioeconomic Background of the Study}

Soil erosion is caused by various natural and hman factors [31]. Natural forces are the forces of nature, such as weather conditions (e.g. rainfall/precipitaiton, temperature, wind, topography of land, and soil structure). Human factors are all human activities conducted on land, especially that relating to the removal of vegetation. Examples are farming; settlement and road construction; and logging activities. Although soil erosion is naturally occuring, human activities however cause it to occur higher than its natural rate, making it devastating. This section therefore provides first, a brief overview of farmer's socioeconomic variables, such as age, education, gender, and annual income. Analysing these variables help to understand the behaviour patterns of people/farmers under study [32]. Also, analyzing these behaviour patterns provide a clue to the behaviour processes of such a population, as well as their production behaviours [33]. Other asspects of this section are the perceived impact of agricultural activities on soil erosion, 
and specific inappropriate agricultural activities contributing to soil erosion in the study area.

TABLE I. SPECIFIC VARIABLES ANALYZED FOR THE STUDY

\begin{tabular}{|c|c|}
\hline Variables & Description \\
\hline $\begin{array}{l}\text { Perceived causes of soil } \\
\text { erosion in the study area }\end{array}$ & $\begin{array}{l}\text { a. Farmers were expected to provide } \\
\text { three most important natural } \\
\text { causes of soil erosion, as perceived } \\
\text { by them } \\
\text { b. Farmers were expected to provide } \\
\text { three most important human } \\
\text { causes of the erosion, as perceived } \\
\text { by them }\end{array}$ \\
\hline $\begin{array}{l}\text { Perceived impact of farming } \\
\text { activities on soil erosion in } \\
\text { study area }\end{array}$ & $\begin{array}{l}\text { An open-ended question, which was later } \\
\text { classified into groups }\end{array}$ \\
\hline $\begin{array}{l}\text { Relative contribution of } \\
\text { various sources to income to } \\
\text { overall income of farmers }\end{array}$ & $\begin{array}{l}\text { Percentage ratings by farmers on the relative } \\
\text { sources of income on their overall income }\end{array}$ \\
\hline $\begin{array}{l}\text { Agricultural systems } \\
\text { practiced by farmers }\end{array}$ & $\begin{array}{l}\text { Farmers were asked to indicate all types of } \\
\text { farming systems practiced in their area }\end{array}$ \\
\hline
\end{tabular}

According to the Table 2, the study area exhibits a problem of ageing phenomenon, with relatively low level of formal education, as average farming age in the area is 53 years, only $6 \%$ exceeded Grade 12, while as high as about $12 \%$ have no formal educaiton. These phenomena is common in many sub-Saharan countries, and the Eastern Cape in particular, which could be a drawback to agricultural development. Although age as a factor in agricultural development is dual and difficult to decide, this result is however consistent with several studies [34], [35], [36], [37], [38], which found that age rather encouraged adoption instead of acting as a drawback. Inadequate education is largely a general problem in the rural areas of the Eastern Cape, as sometimes up to $20 \%$ farmers' population still do not have formal education, and only few exceed Grade 12 level of education [39], [38]. Over and above the impact of other socioeconomic variables in agricultural development, education and poverty play significant roles. According to Pender and Hazell [13], poverty and poor education are two main reasons for inappropriate agricultural decisions by farmers.

TABLE II. SOCIOECONOMIC CHARACTERISTICS OF FARMERS

\begin{tabular}{|c|c|c|c|}
\hline $\begin{array}{l}\text { Variables } \\
\text { Age of farmers } \\
\text { Genderof farmers }\end{array}$ & Statistics & Variables & Statistics \\
\hline \multirow{3}{*}{$\begin{array}{l}\text { Age of farmers } \\
\text { Genderof farmers }\end{array}$} & $\begin{array}{l}\text { Average } \\
\text { (53years) }\end{array}$ & $\begin{array}{l}\text { Education } \\
\text { levels }\end{array}$ & $\begin{array}{l}\text { No formal education } \\
(12 \%)\end{array}$ \\
\hline & Male $(62 \%)$ & & $\begin{array}{l}\text { Exceeded Grade } 12 \\
(6 \%)\end{array}$ \\
\hline & Female $(38 \%)$ & Annual income & $\begin{array}{l}<\mathrm{R} 20000(74 \%) \\
>\mathrm{R} 50000(14 \%)\end{array}$ \\
\hline
\end{tabular}

Source: Survey research 2010

The study area also consisted of a gender disparity, where male farmers (62\%) are more. This finding is inconsistent with some literatures, which suggest that women's contribution to farm production in many developing countries, particularly in sub-Saharan countries, is higher [40]. However, Maka et al. [39] say that the reason for this kind of finding is because of the gender-related economic roles of rural communities in the Eastern Cape, where men are known to engage in farming, while women engage in petty trading. Furthermore, almost three-quarter (74\%) of farmers in the study area earn an annual income of R20000 (R1667/month), showing the poverty level of study area, when compared to the current R3500 minimum wage in South Africa [41].

\section{B. The Role Agricultural Activities Play in Soil Erosion Development}

According to the Table 3, in order of preference, rainfall (26\%), drought (15\%) and wind (13\%) were emphasized as main natural cuases of erosion in the study area, which is consistent with literature [42], [43], [44], [45], [46], [47], [48]. However, amidst all human activities listed by farmers as cause of the erosion problem in their area, agricultural activities (22\%) ranked highest in importance. Although the impact of agriccultural activities is already significant in itself, the situation is worse if impact of other agriculture-related activities, such as deforestation (16\%) and animal footpath $(9 \%)$, is included. As such, the overall effect of agriculture and related activities rises up to almost half (47\%) of the overall effect of all human activities put together.

The impact of agricultural activities in soil erosion development cannot be overemphasized. This could be in a number of ways: through cropping activities or through any form of livestock rearing. Arguing in support, Mukanov et al. [49] say that anthropogenic activities, particularly that of agriculture have a strong positive relationship with soil condition. Citing an example, it was said, that in Northern Kazakhstan, between 1954-1963, the intense development of pasture lands under the Agricultural Program of the Virgin and Fallow Lands, led to large-scale soil degradation [49]. Similarly, El Jazouli et al. [50] maintain that land-use change patterns as a result of intense agricultural practices and deforestation, coupled with population, increased the rate of fertile land deterioratio processes. More so, unrestricted human activities, such as overgrazing, continuous cultivation, and deforestation have been said to be contributing factors for increased soil erosion in Mubi, a town in Nigeria [42].

\section{TABLE III. PERCEIVED NATURAL AND HUMAN REASONS FOR} EROSION IN SHESHEGU

\begin{tabular}{l|l|l|l}
\hline Natural causes of erosion & $\%$ & Human causes of erosion & $\%$ \\
\hline Climate change/variation & 3 & Agricultural activities & 22 \\
Drought & 15 & Animal/human footpath & 9 \\
Heavy rainfall & 26 & Building/construction & 20 \\
Heavy winds & 13 & Deforestation & 16 \\
Inadequate drainage & 1 & Trado-medical uses & 3 \\
Veld fires/burning & 5 & Veld fires/burning & 12 \\
Nature of the soil & 1 & Running water & 1 \\
Slope/gradient of land & 1 & Other & 17 \\
Bare land & 1 & & \\
Other & 35 & & \\
\hline
\end{tabular}

Source: Survey research 2010

\section{Specific Farming Activity Contributing to Soil Erosion in Sheshegu Community}

As indicated, any human activity which tampers or clears off vegetation cover speeds up the rate of soil erosion. In this regard, Chalise et al. [51] argue that the rate at which land/soil degrades is determined by the rate at which land cover degrades. One main land-use factor that largely tampers with vegetation cover is agriculture. This is because of an ever increasing need to feed an ever increasing population. In order therefore to understand specific aspect of agriculture in the study area 
perceived by farmers to be responsible for soil erosion in their area, farmers' perception on their farming systems was sought.

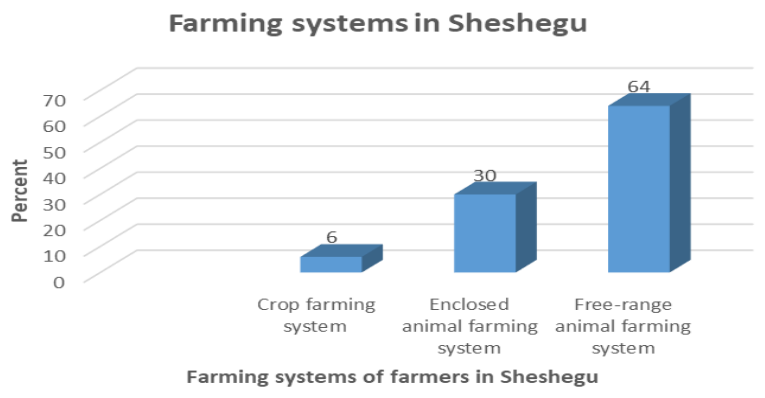

Fig. 1. Systems of farming in Sheshegu community

Findings reveal that three main farming systems (Figure 1) prevail in the study area. In order of importance, the three main farming systems are free-range animal production system (64\%), enclosed animal production system (30\%), and crop production system $(6 \%)$, respectively. Finding on free-range animal production system is highly remarkable, suggesting a possible reason for the soil erosion in the study area. According to Chalise et al. [51], livestock grazing increases soil erosion processes, as large groups of animals regularly trample on land, breaking up soil aggregates, thus making it vulnerable. Citing an example, it was said that increased grazing activities, especially in certain areas of Nepal, has drastically degraded its soil conditions, including the water and nutrient holding ability of the soil [51]. Findings here is however consistent with literature on agriculture in the Eastern Cape Province, which suggest that the Eastern Cape is the largest producer of livestock out of all provinces in South Africa. Concuring, Hoffman and Ashwell (undated) maintainn that $64 \%$ of land in the Eastern Cape is used for livestock rearing, while only $20 \%$ of land is used for cropping. The dominant farming activity in the area is livestock rearing [52], [29].

\begin{tabular}{|c|c|}
\hline Contribution of income sources to overall income & Mean $(\%)$ \\
\hline Government employment & 13.94 \\
\hline Private company & 3.9 \\
\hline Crop farming & 1.72 \\
\hline Enclosed animal farming & 8.82 \\
\hline Free-range animal farming & 18.82 \\
\hline Self-employed(other than farming) & 2 \\
\hline Other sources of income & 48.76 \\
\hline
\end{tabular}

Source: Survey research 2010

To corroborate findings on specific inappropriate farming activity influencing soil erosion in the study area, two other statistics was collected in the study area. These are farmers' perception on the percentage relative contribution of sources of income to their overall income (Table 4), and impact ratings of the impact of inappropriate farming activities on soil erosion development (Table 5). Sources of income help to reveal main human activity providing livelihoods for people in an area, which also helps to reveal the main activity people engage in their environment, which suggest factors that impact on their environment, in this case, the soil. Based on findings (Table 4), apart from other sources of income (49\%), where income from government social welfare grants form the bulk, the relative contribution of income from free-range animal production $(19 \%)$ to overall income of farmers in Sheshegu, ranked highest in importance. This corroborates earlier findings on specific farming activity perceived by farmers as basic cause of soil erosion in the study area. Global agricculture today has experienced great advances, as more sustainable methods have been developed. However, the problem of poverty, lack of education, inadequate technology, lack of technical know-how, et-cetera which prevail in many developing countries, especially in sub-Saharan Africa, is the reason why certain degradation-prone agricultural practices, are still being practiced. As a former homeland area in South Africa, farming among smallholder farmers in the Eastern Cape is largely communal, which provides another dimension to this discussion. Due to a lack of access to personal farmland or large piece of land, that can be converted to a rangeland/pastureland, farmers are constrained to using the already known environment-degrading measures such as free-range animal production.

To further buttress farmers' perceived impact of indescriminate farming activities on soil erosion in the study area, an impact ratings was conducted. This was necessary to provide an understanding of the perceived level of impact, according to farmers. According to findings (Table 5), perceived impact of indescriminate farming activities on soil erosion development rated as high as $90 \%$ of farmers' response. Apart from free-range animal production, which rated higher, other examples of farm practices considered by farmers as impacting on the soil erosion situation in their area includes cropping activities, and tillage practices. According to Le Roux et al. [17], South Africa is susceptible to soil erosion because of inappropriate farm practices, coupled with erodable soils.

\begin{tabular}{l|l|l} 
TABLE V. PERCEIVED IMPACT RATING OF INAPPROPRIATE FARM \\
ACTIVITIES IN STUDY AREA \\
Impact of inappropriate farming activities & Frequency & Percent \\
\hline Highly impacting & 45 & 90 \\
No much impact & 3 & 6 \\
No impact at all & 1 & 2 \\
Other impact & 1 & 2 \\
\hline Total & 50 & 100 \\
\hline \multicolumn{3}{c}{ Source: Survey research 2010}
\end{tabular}

\section{CONCLUSION AND RECOMMENDATIONS}

Although agriculture, and livestock production for that matter is critical for the livelihood of people in the Eastern Cape Province, the problem of soil erosion, largely due to the application of inappropriate farming practices like free-range animal production system, calls for worry. Soil erosion is a naturally occurring phenomenon, but inappropriate human activities however cause it to occur beyond its natural rate, thus making it devastating. This study shows that, though farmers obtain livelihoods from other sources, such as government social welfare grant, livestock (e.g. sheep, cattle and goat) production is the most important source of livelihood for farmers in the study area. However, the production system still prevailing in the study area is the free-range animal production system, which is found to be one of the main agricultural 
activities responsible for soil erosion in many parts of the world. This though could be associated with certain socioeconomic challenges found in the study area, such as poverty and inadequate education, as farmers earn far below the minimum wage, and only $6 \%$ exceeded Grade 12 , while up to about $12 \%$ have no formal education.

It is therefore recommended that the problem of farmers' poverty and inadequate education should be addressed by the government. This could be by providing financial support for farmers to establish their own rangelands, and subsidies should be provided for farmers to purchase animal feeds. Also, adequate awareness is required for farmers in the area on the negative impact of free-range animal production and for other inappropriate practices. Similarly, adequate extension education should be increased in the area, and agriculture should be made more appealing, by encouraging youths right from high schools to see opportunities which lie in farming, and providing soft loans for those who show interest.

\section{REFERENCES}

[1] D. Pimentel, and M. Burgess, "Soil erosion threatens food production," Agriculture, vol. 3, pp. 443-463, August 2013. https://doi.org/10.3390/agriculture3030443

[2] D. Pimentel, "Soil erosion: a food and environmental threat," Environment, Development and Sustainability, vol. 8, pp. 119-137, January 2006. https://doi.org/10.1007/s10668-005-1262-8

[3] R. Engelman, Population, Climate Change and Women's Lives, (Report 183). Washington (DC): Worldwatch Institute, 2010, pp. 21-31.

[4] B. Moya, A. Parker, R. Sakrabani, and B. Mesa, "Evaluating the efficacy of fertilisers derived from human excreta in agriculture and their perception in Antananarivo, Madagascar," Waste Biomass Valor, vol. 10, pp. 941-952, October 2019. https://doi.org/10.1007/s12649-017-0113-9

[5] R. Lal, "Restoring soil quality to mitigate soil degradation," Sustainability, vol. 7, pp. 5875-5895, May 2015. https://doi.org/10.3390/su7055875

[6] DAFF (2011). Policy Brief: Opportunities and Challenges for Climate-Smart Agriculture in Africa. Department of Agriculture, Forestry and Fisheries, Republic of South Africa, Pretoria. [Online]. Available: <https://ccafs.cgiar.org/sites/default/files/assets/docs/au_policyb rief_opportunitieschallenges.pdf $>$.

[7] M.A. Nearing, Y. Xie, B. Liu, and Y. Ye, "Natural and anthropogenic rates of soil erosion," International Soil and Water Conservation Research, vol. 5, pp. 77-84, April 2017. https://doi.org/10.1016/j.iswcr.2017.04.001

[8] S.S. Meijer, D. Catacutan, O.C. Ajayi, G.W. Sileshi, and M. Nieuwenhuis, "The role of knowledge, attitudes and perceptions in the uptake of agricultural agroforestry innnovations among smallholder farmers in sub-Saharan Africa," International Journal of Agricultural Sustainability, vol. 13(1), pp. 40-54, May 2015.

https://doi.org/10.1080/14735903.2014.912493

[9] K. Phinzi, and N.S. Ngetar, "Mapping soil erosion in a quaternary catchment in Eastern Cape using geographic information system and remote sensing," South African Journal of Geomatics, vol. 6(1), pp. 11-29, April 2017. https://doi.org/10.4314/sajg.v6i1.2

[10] L. Tamene, and Q.B. Le, "Estimating soil erosion in sub-Saharan Africa based on landscape similarity mapping and using the revised universal soil loss equation (RUSLE)," Nutr Cycl Agroecosyst, vol. 102, pp. 17-31, January 2015. https://doi.org/10.1007/s10705-015-9674-9

[11] H. Kumar, and P. Pani, "Effects of soil erosion on agricultural productivity in semi-arid regions: the case of lower Chambal valley," Journal of Rural Development, vol. 32(2), pp. 165-184, June 2013.

[12] S. Issaka, and M.A. Ashraf, "Impact of soil erosion and degradation on water quality: a review," Geology, Ecology, and Landscapes, vol. 1(1), pp. 1-11, March 2017. https://doi.org/10.1080/24749508.2017.1301053

[13] J. Pender, and P. Hazell (Eds.), Promoting Sustainable Development in Less-favoured Areas Overview. Washington D.C.: International Food Policy Research Institute (IFPRI), 2000, p. 18.

[14] D.R. Montgomery, "Soil erosion and agricultural sustainability," PNAS, vol. 104(33), pp. 13268-13272, August 2007. https://doi.org/10.1073/pnas.0611508104

[15] S. Zingore, J. Mutegi, B. Agesa, L. Tamene, and J. Khara, "Soil degradation in sub-Saharan Africa and crop production options for soil rehabilitation," Better Crops, vol. 99(1), pp. 24-26, January 2015.

[16] G. Garland, T. Hoffman, and S. Todd, "Soil Degradation," in Land Degradation in South Africa, T. Hoffman, S. Todd, Z. Ntshona, and S. Turner, Eds. Claremont, South Africa: National Botanical Institute, 1999, ch. 6, pp. 69-107.

[17] J.J. Le Roux, T.S. Newby, and P.D. Sumner, "Monitoring soil erosion in South Africa at a regional scale: review and recommendations,", South African Journal of Science, vol. 103, pp. 329-335, July/August 2007.

[18] E. Lahiff, and B. Cousins, "Smallholder agriculture and land reform in South Africa," IDS Bulletin, vol. 36(2), pp. 127-131, February 2005.

https://doi.org/10.1111/j.1759-5436.2005.tb00209.x

[19] G.T. Rootman, J.B. Stevens, and N.M. Mollel, "Policy opportunities to enhance the role of smallholder livestock systems in Limpopo province of South Africa," S. Afr. Tydskr. Landbouvoorl./S. Afr. J. Agric. Ext., vol. 43(2), pp. 91-104, January 2015. https://doi.org/10.17159/2413-3221/2015/v43n2a360

[20] M. Hamann, and V. Tuinder, Introducing the Eastern Cape: A Quick Guide to its History, Diversity and Future Challenges (A Report), Stockholm Resilience Centre. Stockholm: Stockholm University, p. 26.

[21] DEA, (2011). South Africa's Second National Communication Under the United Nations Framework Convention on Climate Change. Department of Environmental Affairs, Republic of South Africa, Pretoria. [Online]. Available: <https://www.sanbi.org/wp-content/uploads/2018/03/201111sas ncpubl.pdf $>$.

[22] P.K. Thornton, et al., "Beyond the metropolis: small town case studies of urban and peri-urban agriculture in South Africa," Urban Forum, vol. 19, pp. 243-262, May 2008. https://doi.org/10.1007/s12132-008-9036-7

[23] R. Parhanse, "Peripheral small town development: Senqu municipality, Eastern Cape Province, South Africa," Urban Forum, vol. 18, pp. 105-115, July 2007. https://doi.org/10.1007/s12132-007-9005-6

[24] World Bank, Overcoming poverty and inequality in South Africa. Washington D.C.: The World Bank, 2018.

[25] J.J. Le Roux, T.L. Morgenthanl, J. Malherbe, D.J. Pretorius, and P.D. Sumner, "Water erosion prediction at a national scale for South Africa," Water SA, vol. 34(3), pp. 305-314, July 2008. https://doi.org/10.4314/wsa.v34i3.180623 
[26] Google Earth, (2009). Google Map. [Online]. Available: http://google-earth-pro.en.so(Earth,2009)ftonic.com.

[27] L. Kom, "Sheep flock structure, dynamics, management practices, and wool production under bush encroached and non-encroached areas of the Eastern Cape Province, South Africa," Master's dissertation, Department of Livestock and Pasture Science, University of Fort Hare, RSA, 2017.

[28] Fort Hare Research Farm, Annual Report, University of Fort Hare, Alice, South Africa, 2001.

[29] I.D. Ighodaro, F.S. Lategan, and S.F.G. Yusuf, "The impact of soil erosion on agricultural potential and performance of Sheshegu community farmers in the Eastern Cape of South Africa," Journal of Agricultural Science, vol. 5(5), pp. 140-147, April 2013. https://doi.org/10.5539/jas.v5n5p140

[30] Statistics South Africa, Statistics South Africa Annual Report 2002/2003. Pretoria: Statistics South Africa, 2003.

[31] M. Belayneh, T. Yirgu, and D. Tsegaye, "Potential soil erosion estimation and area prioritization for better conservation planning in Gumara watershed using RUSLE and GIS techniques," Environ Syst Res, vol. 8(20), pp. 1-17, June 2019 https://doi.org/10.1186/s40068-019-0149-x

[32] M.E. Shaw, and P.R. Constanzo, Theories of Social Psychology. New York: McGraw Hill, 1970, pp. 122-125.

[33] F.S. Lategan, and P. du P. van Niekerk, "An analysis of perceived prominent decision making areas in commercial springbuck (Antidorcas Marsupialis) production decision making," S. Afr. Tydskr. Landbouvoorl./S. Afr. J. Agric. Ext., vol. 36, pp. 249-268, January 2007.

[34] A.A. Agidew, and K.N. Singh, "Factors affecting the adoption of sustainable land management practices at farm level in the Northern Highlands of Ethiopia: the Teleyaven Sub-Watershed case study," J. Environ Pollut Manage, vol. 2(1), pp. 1-12, April 2019. https://doi.org/10.1186/s13717-018-0128-6

[35] A.A. Biratu, and D.K. Asmamaw, "Farmers' perception of soil erosion and participaltion in soil and water conservation activities in the Gusha Temela watershed, Arsi, Ethiopia," International Journal of River Basin Management, vol. 14(3), pp. 329-336, May 2016. https://doi.org/10.1080/15715124.2016.1167063

[36] M. Mwangi, and S. Kariuki, "Factors determining adoption of new agricultural technology by smallholder farmers in developing countries,", Journal of Economics and Sustainable Development, vol. 6(5), pp. 208-216, January 2015.

[37] D. Abebaw, and M.G. Haile, "The impact of cooperatives on agricultural technology adoption: empirical evidence from Ethiopia," Food Policy, vol. 38, pp. 82-91, February 2013. https://doi.org/10.1016/j.foodpol.2012.10.003

[38] I.D. Ighodaro, A. Mushunje, B.F. Lewu, and B.E. Omoruyi, "Climate-smart agriculture and smallholder farmers' income: the case of soil conservation practice-adoption at Qamata Irrigation Scheme, South Africa," J Hum Ecol, 69(1-3), pp. 81-94, January 2020. https://doi.org/10.31901/24566608.2020/69.1-3.3207

[39] L. Maka, I.D. Ighodaro, and G.P.T. Ngcobo-Ngotho, "Capacity development for scaling up climate-smart agriculture (CSA) innovations: agricultural extension's role in mitigating climate change effects in Gqumashe community, Eastern Cape, South Africa," S. Afr. J. Agric. Ext., vol. 47(1), pp. 45-53, January 2019. https://doi.org/10.17159/2413-3221/2019/v47n1a488

[40] T. Paris, M.F. Rola-Rubzen (Eds.), Gender Dimension of Climate Change Research in Agriculture (Case Studies in South east Asia). Wageningen, Netherlands: CGIAR Research Program on
Climate Change, Agriculture and Food Security (CCAFS), 2018, ch. 7, p. 124.

[41] The Presidency, Republic of South Africa, "The national minimum wage act 2018," Government Gazette, Republic of South Africa, vol. 641(42060), pp. 1-21, November 2018.

[42] A.A. Sadiq, M. Abdullahi, and A.U. Ardo, "An overview of soil fertility degradation in Mubi area, north-east part of Nigeria," International Journal of Scientific and Research Publications, vol. 9(2), pp. 692-697, January 2019. https://doi.org/10.29322/IJSRP.9.02.2019.p8685

[43] L. Zhao, and R. Hou, "Human causes of soil loss in rural karst environments: a case study of Guizhou, China," Scientific Reports, vol. 9(3225), pp. 1-11, March 2019. https://doi.org/10.1038/s41598-018-35808-3

[44] S. Berberoglu, A. Cilek, M. Kirkby, B. Irvine, and C. Donmez, "Spatial and temporal evaluation of soil erosion in Turkey under climate change scenarios using the Pan-European Soil Erosion Risk Assessment (PESERA) model," Environ Monit Assess, vol. 192(491), pp. 1-22, July 2020. https://doi.org/10.1007/s10661-020-08429-5

[45] P.N.T. Madikizela, "Spatial and temporal aspects of soil erosion in Mt. Ayliff and Mt Frere, Eastern Cape Province, South Africa”, M.Sc dissertation, School of Applied Environmental Sciences, University of Natal, Pietermaritzburg, South Africa, 2000.

[46] A. Abdelraheem, N. Esmaeili, M. O' Connell, and J. Zhang, "Progress and perspective on drought and salt stress tolerance in cotton," Industrial Crops \& Products, Vol.130, pp. 118-129, December 2019. https://doi.org/10.1016/j.indcrop.2018.12.070

[47] P. Panagos, and A. Katsoyiannis, "Soil erosion modelling: the new challenges as the result of policy developments in Europe," Environmental Research, vol. 172, pp. 470-474, May 2019. https://doi.org/10.1016/j.envres.2019.02.043

[48] P. Borrelli, et al., "Land use and climate change impacts on global soil erosion by water," PNAS, vol. 117(36), pp. 21954-22001. https://doi.org/10.1073/pnas.2001403117

[49] Y. Mukanov, "Estimation of annual average soil loss using the Revised Universal Soil Loss Equation (RUSLE) integrated in a Geographic Information System (GIS) of the Esil River basin (ERB), Kazakhstan," Acta Geophysica, vol. 67, pp. 921-938, May 2019. https://doi.org/10.1007/s11600-019-00288-0

[50] A. El Jazouli, A. Barakat, R. Khellouk, J. Rais, and M. El Baghdadi, "Reomote sensing and GIS techniques for prediction of land use land cover change effects on soil erosion in the high basin of the Oum Er Rbia River (Morocco)," Remote Sensing Applications: Society and Environment, vol. 13, pp. 361-374, December 2019.

https://doi.org/10.1016/j.rsase.2018.12.004

[51] D. Chalise, L. Kumar, and P. Kristiansen, "Land degradation by soil erosion in Nepal: a review," Soil Syst, vol. 3(12), pp. 1-18, February 2019.

https://doi.org/10.3390/soilsystems3010012

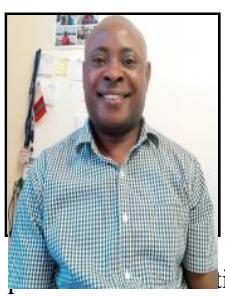

Francis B. Lewu (BSc Agriculture, MSc Agronomy $\& \mathrm{PhD}$ in Botany) started his career as a Genebank Research Assistant in the International Institute of Tropical Agriculture, (IITA). After a postdoctoral study at Fort Hare University, he joined the Department of Agriculture, University of Zululand, South Africa as a Lecturer in 2008 and was appointed acting HOD, of the department in January 2009; a ill end of May 2011. Francis Lewu joined the Cape Peninsula University of Technology (CPUT) as HOD of Agriculture Department in the Faculty of Applied Sciences in June 2011. He was 
appointed Associate Professor in 2014 and he is C3 Established NRF Scholar of South Africa since 2014. In September 2018, Lewu was appointed a Professor in Plant Science at CPUT. Prof Lewu is a qualified Professional Natural Scientist (Pr. Sci. Nat) and has supervised and mentored masters and doctoral students. Lewu concentrates his research effort on the autecology and propagation of medicinal species and alternative cultivation protocols for field crops and horticultural species. He is an editorial member of many journals and serves as a reviewer and evaluator to the NRF and reviewer to several local and international journals. He examines many masters and doctoral theses for several universities. Lewu has published over thirty-five articles in several fields of plant, soil and environmental sciences with a citation index of 9 on Scopus and $14 \mathrm{~h}$-index on Google Scholar. 